\title{
Bathymetric preference of four major genera of rectilinear benthic foraminifera within oxygen minimum zone in Arabian Sea off central west coast of India
}

\author{
Abhijit Mazumder ${ }^{1, *}$ and Rajiv Nigam ${ }^{2}$ \\ ${ }^{1}$ Birbal Sahni Institute of Palaeobotany, 53 University Road, Lucknow 226 007, India. \\ ${ }^{2}$ National Institute of Oceanography, Dona Paula, Goa 403004 , India. \\ ${ }^{*}$ Corresponding author.e-mail: abhimazumder@gmail.com; abhijit_mazumder@bsip.res.in
}

Fifty two surface sediment samples collected from the region off Goa, central west coast of India from water depths of 15-3300 m were analyzed with special emphasis on foraminiferal content. Rectilinear benthic foraminiferal morphogroup shows a high relative abundance within Oxygen Minimum Zone (OMZ), both shallow marine (50-60 m water depth) and intermediate to deep water (150-1500 m water depth). We gave special emphasis on four rectilinear foraminiferal genera, namely Fursenkoina, Bolivina, Bulimina and Uvigerina to observe their individual distribution among OMZ. We found genus Fursenkoina predominates at the shallow water OMZ, within the water depth zone of 50-60 m. Within 150-1500 m water depth, which is considered as intermediate to deep water OMZ in this region, genus Uvigerina shows its highest abundance above $1000 \mathrm{~m}$ water depth, whereas genus Bulimina shows its affinity with deeper water environment ( $>1000 \mathrm{~m}$ water depth). Genus Bolivina does not show any such depth preference, except its higher abundance in only intermediate to deep water OMZ. This depth differentiation among four rectilinear benthic foraminiferal genera presents the basic data for palaeoclimatic study based on the extent and intensity of OMZ along with the palaeobathymetry study.

\section{Introduction}

The formation of a stable mid-water (150-1400 m) Oxygen Minimum Zone (OMZ) in the Arabian Sea is the product of both the high primary productivity and a pronounced thermohaline stratification (Wyrtki 1973; Olson et al. 1993; You and Tomczak 1993; Helly and Levin 2004). The oxygen concentrations within this OMZ exhibit a range below $0.5 \mathrm{ml} / 1$ (Levin 2003) or less than $50 \mu \mathrm{mol} / \mathrm{l}$ (Fuenzalida et al. 2009). Oxygen consumption by decay of organic matter, supply of less oxygenated intermediate water-masses from the south and west (Swallow 1984; Olson et al. 1993) and the semienclosure morphology of the northern Arabian Sea
(Wyrtki 1973; Shetye et al. 1994) are the main factors responsible for this low oxygen concentration. Apart from this OMZ, a shallow water oxygen depleted zone ( $\sim 50-60 \mathrm{~m})$ has been reported from different parts of world (Turner and Rabalais 1994; Sen Gupta et al. 1996; Malakoff 1998; Rabalais 2000; Osterman 2003), including eastern Arabian Sea (Naqvi et al. 2000). The level of oxygen concentration of this shallow water OMZ is much less than $(<5 \mu \mathrm{mol} / \mathrm{l})$ the conventional deep water $\mathrm{OMZ}$ (Donoso and Escribano 2013).

Benthic foraminifera have long been used as a very valuable tool to reconstruct paleoceanographic characters (Gooday 2003), including paleooxygenation (Kaiho 1994; Bernhard et al. 1997;

Keywords. Fursenkoina; Bolivina; Bulimina; Uvigerina; Oxygen minimum zone; Arabian Sea. 
Jorissen 1999; Den Dulk et al. 2000; Gooday 2003). It was seen earlier that the faunal diversity and density of benthic foraminifera have a general dependency on the oxygenation of bottomand sediment pore-water (Jorissen et al. 1995; Fontanier et al. 2002).

Higher percentage in abundance of certain benthic foraminifera groups, viz., the species under the genus Bolivina, in oxygen-depleted environments have been reported (Phleger and Soutar 1973; Mackensen and Douglas 1989; Bernhard 1993; Sen Gupta and Machain-Castillo 1993; Alve 1994, 1995; Bernhard et al. 1997; Jorissen et al. 1998; Bernhard and Sen Gupta 1999; Gooday et al. 2000; Fontanier et al. 2002). Another rectilinear benthic foraminiferal genus Uvigerina has also widely been used for palaeoenvironmental and palaeoceanographic studies (Boersma 1984; Lutze 1986; Raju and Dave 1996; Cannariato et al. 1999; Asioli et al. 2001; Lokho et al. 2004; Schweizer et al. 2008). Bandy (1960) correlated the test morphology of uvigerinids and bathymetry. Spencer (1992) studied 12 benthic foraminifera species, including two species of Bolivina and a single species of Uvigerina, with the bathymetrical variation from the northern Gulf of Mexico. But there is no attempt to correlate the total population of any important genus of rectilinear foraminifera with the change of bathymetry within oxygen-depleted zone. However, several other reports indicated that some rectilinear forms of benthic foraminifera, viz., Bolivina, Fursenkoina, Uvigerina, Bulimina, Buliminella, Stainforthia, Brizalina, Loxostomum, etc., are the most abundant genera present in hypoxic regions (Kaiho 1994; Bernhard and Sen Gupta 1999).

In eastern Arabian Sea region, composition and abundance of benthic foraminifera were studied with respect to changes of oxygen concentration (Den Dulk et al. 2000; Nigam et al. 2007, 2009; Schumacher et al. 2007). Nigam et al. (2007) reported the abundance $(>40 \%)$ of a rectilinear morphogroup among benthic foraminifera within OMZ of central eastern Arabian Sea. Mazumder et al. (2003) reported the noticeable abundance of Bulimina costata within OMZ. But no major attempt has yet been made to demark the generic importance to delineate the presence of both OMZs in Arabian Sea region.

The main objective of the present paper is to observe and compare the spatial variation of a few important genera of rectilinear benthic foraminifera between the shallow- and deepwater OMZ off central west coast of India to define the generic importance in detecting the characterization of oxygen-depleted environment in accordance to the bathymetric depth of ocean.

\section{Materials and methods}

During the cruise of ORV Sagar Kanya (SK-117), 52 sediment samples were collected by Spade Corer from the region off Goa (Vijaydurg to Bhatkal) of central west coast of India from water depths of 15-3300 m, which were used for this study (figure 1). Sediment samples of $0-2 \mathrm{~cm}$ each was processed through $63 \mu \mathrm{m}$ sieve after treating with Sodium Hexa-metaphosphate and Hydrogen Peroxide to remove the clayey particles and organic matters, respectively. Total (non-stained) benthic foraminifera were picked from the $+63 \mu \mathrm{m}$ (sand) fraction of each sample. A minimum of 300 specimens of benthic foraminifera were picked, identified up to species level and counted with respect to total benthic foraminifera population. The samples were labelled and preserved at the National Institute of Oceanography, Goa repository. The presence of agglutinated benthic foraminifera species confirm that the used samples are of recent age.

Special emphasis was placed on rectilinear benthic foraminifera, a particular morphological form of benthic foraminifera reported as indicator of OMZ in Arabian Sea region (Nigam et al. 2007). Within this group, we gave more importance to four important genera which show high abundance; namely, Bolivina, Bulimina, Fursenkoina and Uvigerina. The relative percentages of these four genera among the total rectilinear benthic foraminifera were plotted against the depth profile of the study area (figure 2).

\section{Result}

In the present study, we found 21 species of Bolivina (+Brizalina + Bolivinella + Bolivinita $), 8$ species of Bulimina (+Buliminella), 18 species of Uvigerina (+Euuvigerina + Neouvigerina + Siphouvigerina) and 9 species of Fursenkoina $(+$ Virgulina + Virgulinella + Stainforthia $)$, among 423 species of foraminifera under 163 genera (table 1). Relative abundance of all species under these four major groups of genera of rectilinear foraminifera shows distinct characters with respect to OMZ (figure 2). Genus Uvigerina shows a relative abundance $>10 \%$ among all rectilinear groups within the intermediate OMZ up to $\sim 1000 \mathrm{~m}$ water depth. On the contrary, genus Bulimina shows a higher percentage $(>20 \%)$ within intermediate OMZ but below $\sim 1000 \mathrm{~m}$ water depth. Genus Bolivina, however, shows its peak in abundance with $>20 \%$ within and around the intermediate OMZ. On the other hand, genus Fursenkoina shows a distinct peak (>60\% abundance among all rectilinear forms) within the shallow water oxygen-depleted zone. From this 


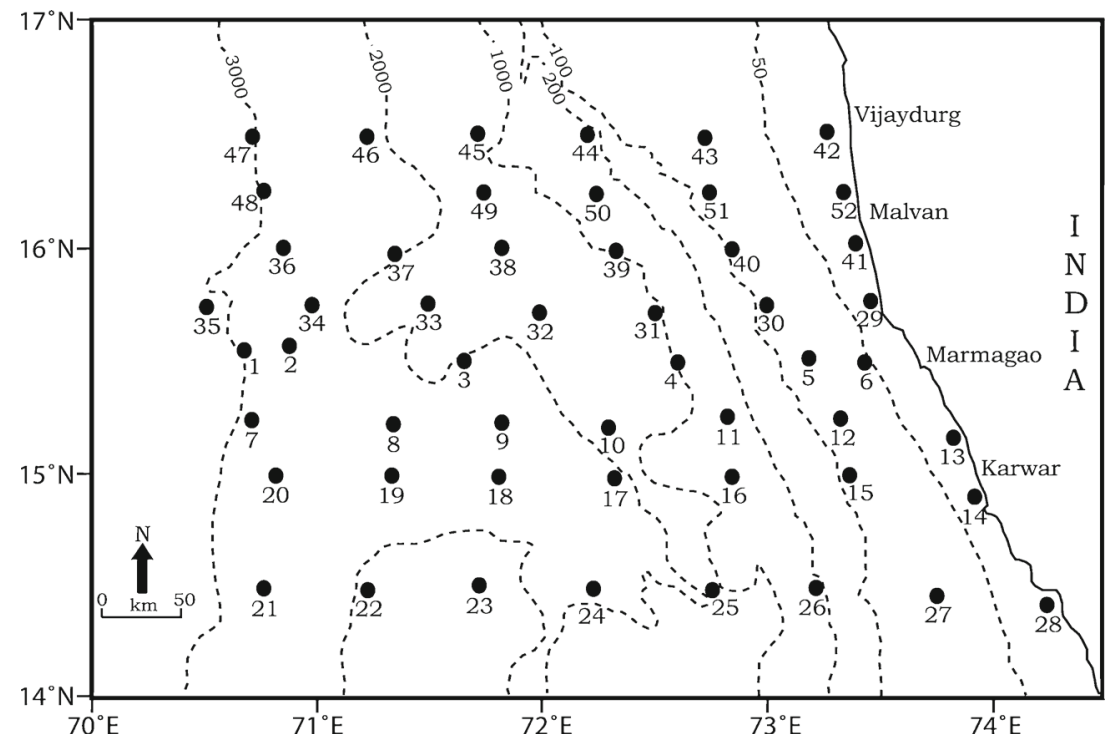

Figure 1. Location of 52 surface sediment samples from eastern Arabian Sea used for the present study.

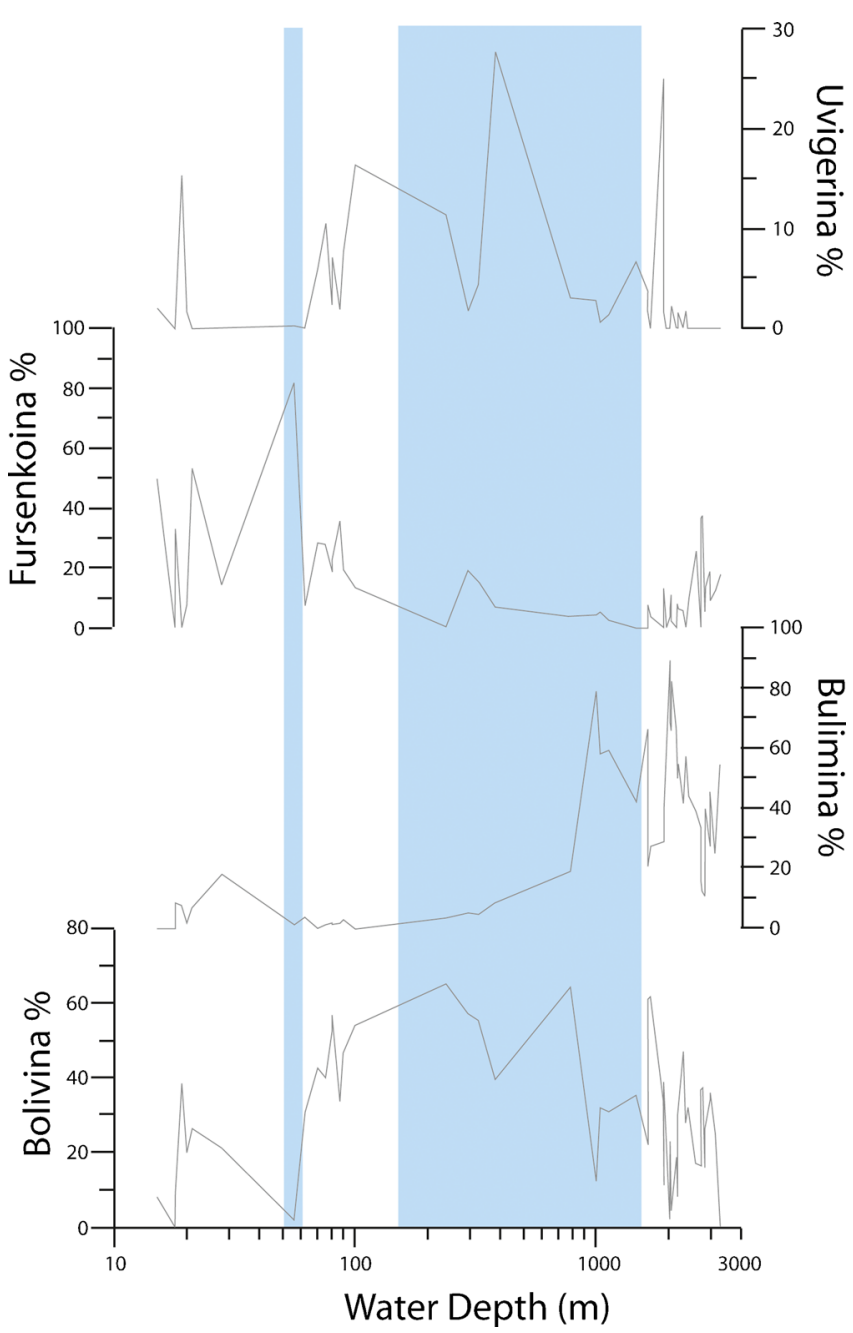

Figure 2. Surface abundance of genera Uvigerina, Fursenkoina, Bulimina and Bolivina. The shaded areas show the depth of OMZ (shallow and intermediate-deep water). result, it is postulated that among rectilinear forms of benthic foraminifera, the abundance of genus Fursenkoina is triggered by less oxygen concentration in the shallow water environments $(50-60 \mathrm{~m}$ water depth). On the other hand, the genera Bolivina, Uvigerina and Bulimina show their high abundance within the intermediate OMZ, but Uvigerina is abundant above $\sim 1000 \mathrm{~m}$ water depth, whereas Bulimina is predominated below $\sim 1000 \mathrm{~m}$ water depth.

\section{Discussion}

Regions of less oxygen concentration in different parts of world oceans have been reported and studied in different aspects (Wyrtki 1962; Sen Gupta et al. 1980; Turner and Rabalais 1994; Osterman 2003). Low oxygenated water with the concentration of oxygen $<0.5 \mathrm{ml} / \mathrm{l}$ predominates in the water depths of $\sim 100 \mathrm{~m}$ to $\sim 1000-\sim 1250 \mathrm{~m}$ worldwide (Stackelberg 1972; Sen Gupta et al. 1976; Naqvi 1994; Levin et al. 2000). Moreover, Turner and Rabalais (1994), Malakoff (1998) and Rabalais (2000) reported the presence of shallow water oxygen depleted zone with the oxygen concentration of $<5 \mu \mathrm{mol} / \mathrm{l}$ (Donoso and Escribano 2013). Similar type of shallow water oxygen depletion was recorded along central west coast of India (Sen Gupta and Naqvi 1984; Naqvi et al. 2000). Nigam et al. (2007) proposed the relative abundance of rectilinear morphogroups of benthic foraminifera as a good indicator for oxygen depleted zone in both shallow (50-60 m water depth) and intermediate water depths (90-1200 m water depth).

The abundance of genus Uvigerina is reportedly dependant on water depth (Schnitker 1979; 
Table 1. List of rectilinear foraminifera grouped under four major genera.

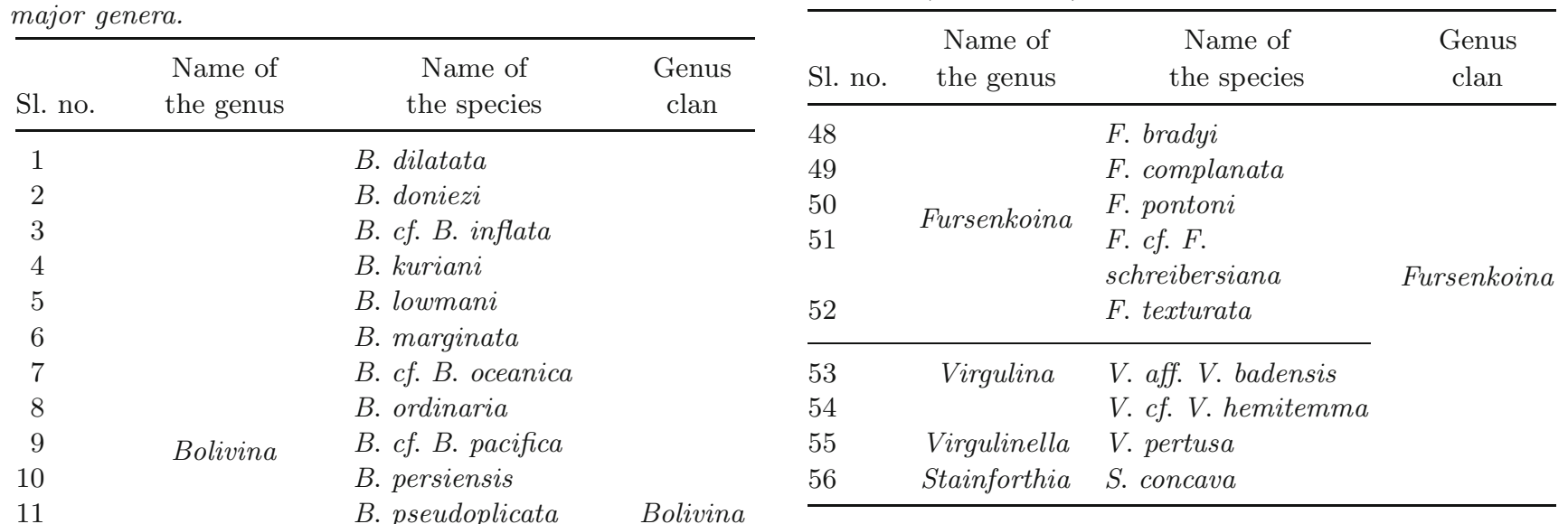

Table 1. (Continued.)
12 B. robusta

13 B. seminuda

14 B. silvestrina

15 B. spinata

16 B. spinescens

17 B. variabilis

18 Bolivina sp.

\begin{tabular}{lll}
\hline 19 & Brizalina & B. difformis \\
20 & Bolivinella & B. elegans \\
21 & Bolivinita & B. quadrilatera
\end{tabular}

\begin{tabular}{|c|c|c|c|}
\hline 22 & & B. aculeata & \\
\hline 23 & & B. alazanensis & \\
\hline 24 & & B. biserialis & \\
\hline 25 & Bulimina & B. exilis & Bulimina \\
\hline 26 & & B. gibba & \\
\hline 27 & & B. marginata & \\
\hline 28 & & B. mexicana & \\
\hline 29 & Buliminella & B. cf. B. milletti & \\
\hline 30 & Euuvigerina & E. aculeata & \multirow{18}{*}{ Uvigerina } \\
\hline 31 & & $\int N$ ampullacea & \\
\hline 32 & Neouvigerina & $\{N$. interrupta & \\
\hline 33 & Siphouvigerina & S. porrecta & \\
\hline 34 & \multirow{14}{*}{ Uvigerina } & U. asperula & \\
\hline 35 & & U. cf. U. auberiana & \\
\hline 36 & & U. bassensis & \\
\hline 37 & & U. bifurcata & \\
\hline 38 & & U. brunensis & \\
\hline 39 & & U. canariensis & \\
\hline 40 & & U. hollicki & \\
\hline 41 & & U. mediterranea & \\
\hline 42 & & $U$. peregrina & \\
\hline 43 & & U. proboscidea & \\
\hline 44 & & $U$. vadescens & \\
\hline 45 & & U. schwageri & \\
\hline 46 & & Uvigerina sp. A & \\
\hline 47 & & Uvigerina sp. $B$ & \\
\hline
\end{tabular}

Streeter and Lavery 1982; Caralp 1987). For example, one species of Uvigerina, U. semiornata was reported abundantly from the water depth of $233 \mathrm{~m}$ at the Indo-Pakistan Continental Margin (Maas 2000) and U. phlegeri along with U. peregrina was reported at the water depth of $500 \mathrm{~m}$ off Karachi region (Jannink et al. 1998). U. peregrina shows abundance below $500 \mathrm{~m}$ water depth, both in the northwestern (Hermelin and Shimmield 1990) and in the northeastern part (Jannink et al. 1998; Maas 2000). Jannink et al. (1998) surmised that the particular depth zone of maximum abundance of $U$. peregrina is within 1000 to $1254 \mathrm{~m}$ water depth in northeastern Arabian Sea. U. semiornata was reported to decrease significantly with water depth after $500 \mathrm{~m}$ (Schumacher et al. 2007). This genus was also reported with high percentage from the oxygen depleted areas. Two species of Uvigerina, namely, $U$. auberiana and $U$. peregrina show their dominance in the upper to uppermost lower continental slope area (Szarek et al. 2009), i.e., less oxygenated conditions (Jian et al. 1999; Kuhnt et al. 1999). In Atlantic Ocean sediment cores, high abundance of $U$. peregrina has been reported during the Last Glacial (Lutze 1986; Caralp 1987), which can be attributed to the presence of less oxygen deep-water (Streeter and Shackleton 1979; Caralp 1987). U. peregrina was reported in moderately oxygen-depleted areas, e.g., off California (Bernhard 1992) and in the Angola Basin (Van Leeuwen 1989). U. auberiana is among the few most important species reported from the OMZ of Sunda Shelf, South China Sea (Szarek et al. 2009). But, surprisingly, species of Uvigerina are comparatively rare in most previously described faunas from less oxygen water from other parts of the world, than in the Arabian Sea OMZ (Schumacher et al. 2007). In our study area, the genus Uvigerina shows the higher percentage $(>10 \%$ among all rectilinear) within the bathymetric depth of $\sim 100 \mathrm{~m}$ to $\sim 1000 \mathrm{~m}$, which is in concordance with both the bathymetric restriction for this genus 
and characteristic effect of lower concentration of oxygen. However, the important finding of the present study is that Uvigerina is mainly restricted within $\sim 1000 \mathrm{~m}$ water depth, except for a single location below $1000 \mathrm{~m}$. So the presence of this genus, irrespective of its species constituents, demarcates the oxygen-depleted water mass with a depth restriction of 100-1000 m.

Bolivina dilatata has been reported from the northeastern Arabian Sea at 230 m (Maas 2000) and $550 \mathrm{~m}$ water depth (Jannink et al. 1998), and B. seminuda from Oman margin at $412 \mathrm{~m}$ (Gooday et al. 2000). Jannink et al. (1998) reported that $B$. dilatata and $B$. exilis were dominant around $500 \mathrm{~m}$ in northeastern Arabian Sea. Bulimina exilis was reported as an important component within the water depth of 306-738 $\mathrm{m}$ off Pakistan region (Schumacher et al. 2007). Hermelin and Shimmield (1990) noted that the upper bathyal (440-640 m) assemblages were predominated by higher population of species under Bulimina and Bolivina. In Santa Catalina basin oxygen depleted zone, Bolivina spissa was reported to be one of the predominant species (Mackensen and Douglas 1989), while in the Santa Barbara basin oxygen depleted zone, Bolivina seminuda, B. argentea and Bulimina tenuata are a few common taxa (Bernhard et al. 1997). Sen Gupta and Machain-Castillo (1993) reported small thin-shelled forms of Bolivina and Bolivina-like species from the southern East Pacific margin OMZ. Szarek et al. (2009) reported abundant Bolivina robusta from the OMZ of Sunda Shelf, South China Sea. Bolivina decussate is one of the important species found within the OMZ from northern Japan (Shibahara et al. 2007). In the present study, genus Bolivina shows its higher abundance between $\sim 70$ and $\sim 1500 \mathrm{~m}$, which overlaps the intermediate OMZ in this region. Therefore, Bolivina can be considered as a very good indicator of intermediate oxygen depleted zone in the study area. On the other hand, Bulimina shows its peak highest abundance from $\sim 800$ to $\sim 2000 \mathrm{~m}$ water depth. In this case, genus Bulimina shows a tendency to flourish within less oxygenated water, towards a greater water depth. Hence, Bolivina can be used to detect the total range of intermediate to deep water OMZ, while Bulimina can show its restriction to only deeper part of OMZ (>1000 m).

Shibahara et al. (2007) reported two species of Fursenkoina, namely $F$. cornuta and $F$. rotundata which are characteristic forms of benthic foraminifera of suboxic condition in northeastern Japan. Fursenkoina fusiformis is reported as the marker for an increased supply of organic matter which indicates the transition from the glacial to the interglacial periods (Ventura et al. 2010). The increased supply of organic matter is one of the causes for low oxygen levels in OMZ (Sarma 2002). Angulogerina angulosa, Bolivina costata, B. interjuncta, B. plicata, B. seminuda, Bolivinita minuta, Cancris carmenensis, Fursenkoina fusiformis, Nonionella stella, Uvigerina peregrine and Valvulineria glabra are very common species in the OMZ off Peru (Mallon et al. 2012). In the present study, the genus Fursenkoina shows a high abundance ( $>60 \%$ among all rectilinear forms) within the shallow water depth, especially within 50-60 m water depth. As Furenkoina is reported from the less oxygenated water from different parts of world, it can be postulated that the water depth zone of 50-60 $\mathrm{m}$ shows suboxic condition of water where the Fursenkoina shows the maximum abundance over other rectilinear forms. Hence, the genus Fursenkoina can be used to establish the correlation between the foraminiferal generic abundance with the least oxygenated water $(<5 \mu \mathrm{mol} / \mathrm{l}$ oxygen concentration) in oceanic setting, i.e., shallow water OMZ (50-60 m).

\section{Conclusion}

The four rectilinear benthic foraminiferal genera, namely Bolivina, Bulimina, Uvigerina and Fursenkoina are found to be abundant in the Oxygen Minimum Zone in central part of east Arabian Sea. On the basis of the relative percentage of these genera, their abundance can be distributed within different parts of the OMZ in the study area. Fursenkoina shows its highest abundance in shallow marine OMZ (50-60 m water depth). On the other hand, the genus Bolivina dominates in intermediate to deep water OMZ (150-1500 m water depth). Uvigerina predominates the intermediate water OMZ (150-1000 $\mathrm{m}$ water depth), whereas Bulimina shows its predominance in deep water OMZ (1000-1500 m water depth). The depth preference of these four genera within the OMZ in the study area is very distinctive for distinguishing the depth range within OMZ in eastern Arabian Sea. This characteristic of depth preference by benthic foraminiferal genera can be well applicable for palaeoclimatic study with a special reference to the bathymetric change of OMZ in the past.

\section{Acknowledgements}

The authors express their thanks to the Director, Birbal Sahni Institute of Palaeobotany for permission to publish the results. The authors are also thankful to Mrs S M Bhonsle for her help in processing the samples. A M acknowledges the Council of Scientific and Industrial Research, New Delhi for grant. 


\section{References}

Alve E 1994 Opportunistic features of the foraminifera Stainforthia fusiformis (Williamson): Evidence from Frierfjord, Norway; J. Micropaleontol. 1324.

Alve E 1995 Benthic foraminiferal distribution and recolonization of formerly anoxic environments in Drammensfjord, southern Norway; Mar. Geol. 25 169-286.

Asioli A, Trincardi F, Lowe J J, Ariztegui D, Langone L and Oldfield F 2001 Sub-millennial scale climatic oscillations in the central Adriatic during the Lateglacial: Palaeoceanographic implications; Quat. Sci. Rev. 20 1201-1221.

Bandy O L 1960 General correlation of foraminiferal structure with environment; In: International Geological Congress, XXI Session (Copenhagen) 22 7-19.

Bernhard J M 1992 Benthic foraminiferal distribution and biomass related to porewater oxygen content: Central California continental slope and rise; Deep-Sea Res. 39 585-605.

Bernhard J M 1993 Experimental and field evidence of Antarctic foraminiferal tolerance to anoxia and hydrogen sulfide; Mar. Micropal. 20 203-213.

Bernhard J M and Sen Gupta B K 1999 Foraminifera of oxygen depleted environments; In: Modern Foraminifera (ed.) Sen Gupta B K, Kluwer Academic Publishers, Dordrecht.

Bernhard J M, Sen Gupta B K and Borne P F 1997 Benthic foraminiferal proxy to estimate dysoxic bottom-water oxygen concentrations: Santa Barbara basin, U.S. Pacific continental margin; J. Foram. Res. 27 301-310.

Boersma A 1984 Handbook of common Tertiary Uvigerina (New York: Microclimates Press), 207p.

Cannariato K G, Kennett J P and Behl R J 1999 Biotic response to Late Quaternary rapid climate switches in Santa Barbara Basin: Ecological and evolutionary implications; Geology 27 63-66.

Caralp M H 1987 Deep-sea circulation in the northeastern Atlantic over the past 30,000 years: The benthic foraminiferal record; Oceanol. Acta 10 27-40.

Den Dulk M, Reichart G J, Van Heyst S, Zachariasse W J and Van der Zwaan G J 2000 Benthic foraminifera as proxies of organic matter flux and bottom water oxygenation? A case history from the northern Arabian Sea; Palaeogeogr. Palaeoclimatol. Palaeoecol. 161 337-359.

Donoso K and Escribano R 2013 Mass-specific respiration of mesozooplankton and its role in the maintenance of an oxygen-deficient ecological barrier (BEDOX) in the upwelling zone off Chile upon presence of a shallow oxygen minimum zone; J. Mar. Sys 129 166-177.

Fontanier C, Jorissen F J, Licari L, Alexandre A, Anschutz $\mathrm{P}$ and Carbonel P 2002 Live benthic foraminiferal faunas from the Bay of Biscay: Faunal density, composition, and microhabitats; Deep-Sea Res. II 49 751-785.

Fuenzalida R, Schneider W, Garces-Vargas J, Bravo L and Lange C 2009 Vertical and horizontal extension of the oxygen minimum zone in the eastern south Pacific Ocean; Deep-Sea Res. II 56 992-1003.

Gooday A J 2003 Benthic foraminifera (Protista) as tools in deep-water palaeoceanography: A review of environmental influences on faunal characteristics; Adv. Mar. Biol. 46 1-90.

Gooday A J, Bernhard J M, Levin L A and Suhr S B 2000 Foraminifera in the Arabian Sea oxygen minimum zone and other oxygen deficient settings: Taxonomic composition, diversity, and relation to metazoan faunas; Deep-Sea Res. II 47 24-54.
Helly J and Levin L A 2004 Global distribution of naturally occurring marine hypoxia on continental margins; DeepSea Res. I 51 1159-1168.

Hermelin J O R and Shimmield G B 1990 The importance of the oxygen minimum zone and sediment geochemistry in the distribution of Recent benthic foraminifera in the northwest Indian Ocean; Mar. Geol. 91 1-29.

Jannink N T, Zachariasse W J and Van der Zwaan G J 1998 Living (Rose Bengal stained) benthic foraminifera from the Pakistan continental margin (North Arabian Sea); Deep-Sea Res. I 45 1483-1513.

Jian Z M, Wang L J, Kienast M, Sarnthein M, Kuhnt W, Lin H L and Wang P X 1999 Benthic foraminiferal paleoceanography of the South China Sea over the last 40,000 years; Mar. Geol. 156 159-186.

Jorissen F J 1999 Benthic foraminiferal succession across Late Quaternary Mediterranean sapropels; Mar. Geol. 153 91-101.

Jorissen F J, De Stigter H C and Widmark J G V 1995 A conceptual model explaining benthic foraminiferal microhabitats; Mar. Micropal. 26 3-15.

Jorissen F J, Wittling I, Peypouquet J P, Rabouille C and Relexans J C 1998 Live benthic foraminiferal faunas off Cape Blance, NW-Africa: Community structure and microhabitates; Deep-Sea Res. I 45 21572188.

Kaiho K 1994 Benthic foraminiferal dissolved-oxygen index and dissolved-oxygen levels in the modern ocean; Geology 22 719-722.

Kuhnt W, Hess S and Jian Z 1999 Quantitative composition of benthic foraminiferal assemblages as a proxy indicator for organic carbon flux rates in the South China Sea; Mar. Geol. 156 123-127.

Levin L A 2003 Oxygen minimum zone benthos: Adaptation and community response to hypoxia; Oceanogr. Mar. Biol. 41 1-45.

Levin L A, Gage J D, Martin C and Lamont P A 2000 Macrobenthic community structure within and beneath the oxygen minimum zone, NW Arabian Sea; Deep-Sea Res. II 47 189-226.

Lokho K, Venkatachalapathy R and Raju D S N 2004 Uvigerinids and associated foraminifera: Their value as direct evidence for shelf and deep marine paleoenvironments during Upper Disang of Nagaland, Eastern Himalaya and its implications in hydrocarbon exploration; Indian J. Petrol. Geol. 13 79-96.

Lutze G F 1986 Uvigerina species of the eastern North Atlantic; Utrecht Micropal. Bull. 35 21-46.

Maas M 2000 Verbreitung lebendgefärbter benthischer Foraminiferen in einer intensivierten Sauerstoffminimumzone, Indo-Pakistanischer Kontinentalrand, nördliches Arabisches Meer (Distribution of Rose Bengal stained benthic foraminifera within an intensified oxygen minimum zone, Indo-Pakistan Continental Margin, Northwest Arabian Sea); Meyniana 52 101-128.

Mackensen A and Douglas R G 1989 Down-core distribution of live and dead deep-water benthic foraminifera in box cores from the Weddell Sea and the California continental borderland; Deep-Sea Res. 36 879-900.

Malakoff D 1998 Death by suffocation in the Gulf of Mexico; Science 281 190-192.

Mallon J, Glock N and Schönfeld J 2012 The response of benthic foraminifera to low-oxygen conditions of the Peruvian oxygen minimum zone; In: ANOXIA: Evidence for eukaryote survival and paleontological strategies (eds) Altenbach A V, Bernhard J M and Seckbach J, Cellular Origin, Life in Extreme Habitat and Astrobiology 21 305-321. 
Mazumder A, Henriques P J and Nigam R 2003 Distribution of benthic foraminifera within oxygen minima zone, off central west coast, India; Gond. Geol. Mag. 6 5-10.

Naqvi S W A 1994 Denitrification processes in the Arabian Sea; Proc. Indian Acad. Sci. (Earth Planet. Sci.) 103 279-300.

Naqvi S W A, Jayakumar D A, Narvekar P V, Naik H, Sarma V V S S, D'Souza W, Joseph S and George M D 2000 Increased marine production of $\mathrm{N}_{2} \mathrm{O}$ due to intensifying anoxia on the Indian continental shelf; Nature 408 346-349.

Nigam R, Mazumder A, Henriques $\mathrm{P}$ J and Saraswat R 2007 Benthic foraminifera as proxy for oxygendepleted conditions off the central west coast of India; $J$. Geol. Soc. India 70 1047-1054.

Nigam R, Prasad V, Mazumder A, Garg R, Saraswat R and Henriques P J 2009 Late Holocene changes in hypoxia off the west coast of India: Micropalaeontological evidences; Curr. Sci. 96 708-713.

Olson D B, Hitchcock G L, Fine R A and Warren B A 1993 Maintenance of the low-oxygen layer in the central Arabian Sea; Deep-Sea Res. II 40 673-685.

Osterman L E 2003 Benthic foraminifers from the continental shelf and slope of the Gulf of Mexico: An indicator of shelf hypoxia; Estuarine Coast. Shelf Sci. 58 17-35.

Phleger F B and Soutar A 1973 Production of benthic foraminifera in three east Pacific oxygen minima; Micropaleontol. 19 110-115.

Rabalais N N 2000 Oxygen depletion in coastal waters; NOAA State of the Coast Report, National Oceanic and Atmospheric Administration (NOAA), Silver Spring, Maryland; http://state_of_coast.noaa.gov/bulletins/html/ hyp_09/hyp.htm.

Raju D S N and Dave A 1996 Oligocene to Pleistocene uvigerinids and their value in reconstruction of paleodepths in Krishna-Godavari and Cauvery basins; In: Contributions to XV Indian Micropaleontology and Stratigraphy (eds) Pandey J and Azmi R J et al., Dehra Dun, pp. 189-208.

Sarma V V S S 2002 An evaluation of physical and biogeochemical processes regulating the oxygen minimum zone in the water column of the Bay of Bengal; Global Biogeochem. Cycles 161099.

Schnitker D 1979 Cenozoic deep water foraminifers, Bay of Biscay; In: Init. Repts. DSDP (eds) Montadert L and Roberts D G et al., U.S. Govt. Printing Office, Washington.

Schumacher S, Jorissen F J, Dissard D, Larkin K E and Gooday A J 2007 Live (Rose Bengal stained) and dead benthic foraminifera from the oxygen minimum zone of the Pakistan continental margin (Arabian Sea); Mar. Micropal. 62 45-73.

Schweizer M, Pawlowski J, Kouwenhoven T J, Guiard J and van der Zwaan B 2008 Molecular phylogeny of Rotaliida (Foraminifera) based on complete small subunit rDNA sequences; Mar. Micropal. 66 233-246.

Sen Gupta B K and Machain-Castillo M L 1993 Benthic foraminifera in oxygen-poor habitats; Mar. Micropal. 20 $183-201$.

Sen Gupta R, Braganza A, Noronha R J and Singhbal S Y S 1980 Chemical oceanography of the Arabian Sea. Part V.
Hydrochemical characteristics off the central west coast of India; Indian J. Mar. Sci. 9 240-245.

Sen Gupta B K, Turner R E and Rabalais N N 1996 Seasonal oxygen depletion in continental-shelf waters of Louisiana: Historical record of benthic foraminifers; Geology $\mathbf{2 4}$ 227-230.

Sen Gupta R, Rajagopal M D and Qasim S Z 1976 Relationship between dissolved oxygen and nutrients in the northwestern Indian Ocean; Indian J. Mar. Sci. 5 201-211.

Sen Gupta R and Naqvi S W A 1984 Chemical oceanography of the Indian Ocean, north of the Equator; Deep-Sea Res. I 31 671-706.

Shetye S R, Gouveia A D and Shenoi S S C 1994 Circulation and water masses of the Arabian Sea; In: Biogeochemistry of the Arabian Sea (ed.) Lal D, Proc. Indian Acad. Sci. (Earth Planet. Sci.) 103(2) 107-123.

Shibahara A, Ohkushi K, Kennett J P and Ikehara K 2007 Late Quaternary changes in intermediate water oxygenation and oxygen minimum zone, northern Japan: A benthic foraminiferal perspective; Paleoceanogr. 22 PA3213.

Spencer R S 1992 Quantified intraspecific variation of common benthic foraminifera from the Northwest Gulf of Mexico: A potential paleobathymetric indicator; $J$. Foram. Res. 22 274-292.

Stackelberg U V 1972 Faziesverteilung in Sedimenten des Indisch-Pakistanischen Kontinental-Randes (Arabisches Meer); Meteor Forschungsgebn Reihe C 9 1-73.

Streeter S S and Lavery S A 1982 Holocene and latest glacial benthic foraminifera from the slope and rise off eastern North America; Geol. Soc. Am. Bull. 93 190-199.

Streeter S S and Shackleton N J 1979 Paleocirculation of the deep north Atlantic: 150,000 year record of benthic foraminifera and oxygen-18; Science 203 168-171.

Swallow J C 1984 Some aspects of the physical oceanography of the Indian Ocean; Deep-Sea Res. 31 639-650.

Szarek R, Kuhnt W, Kawamura H and Nishi H 2009 Distribution of recent benthic foraminifera along continental slope of the Sunda Shelf (South China Sea); Mar. Micropal. 71 41-50.

Turner R E and Rabalais N N 1994 Coastal eutrophication near the Mississippi river delta; Nature 368 619-621.

Van Leeuwen R J W 1989 Sea-floor distribution and Late Quarternary faunal patterns of planktonic and benthic foraminifers in the Angola basin; Utrecht Micropaleontol. Bull. 38 1-288.

Ventura C, Voelker A H L and Fatela F 2010 Benthic foraminifera assemblages as responses to climate variations during MIS 14 to 9 on the mid-depth Portuguese margin; Abstract Volume, Forams 2010, Int. Symp. on Foraminifera, Bonn, Germany, 194p.

Wyrtki K 1962 The oxygen minima in relation to ocean circulation; Deep-Sea Res. Oceanogr. Abstracts 9 11-23.

Wyrtki K 1973 Physical oceanography of the Indian Ocean; In: The Biology of the Indian Ocean (ed.) Zeitschel B; Springer, Berlin.

You Y and Tomczak M 1993 Thermocline circulation and ventilation in the Indian Ocean derived from water mass analysis; Deep-Sea Res. I 40 13-56. 